\title{
PENGARUH PENGGUNAAN JEJARING SOSIAL TERHADAP PRODUKTIVITAS PEBISNIS ONLINESHOP DENGAN MOTIVASI SEBAGAI VARIABEL MODERASI
}

\author{
Oleh : \\ Fitri Hidayati ${ }^{1}$ \\ Wenny Desty Febrian² \\ wenny.sani27@gmail.com \\ UIN Suska Riau' \\ Universitas Dian Nusantara ${ }^{2}$
}

\begin{abstract}
The development of technology is increasingly advanced and rapid and is accompanied by a higher level of need for the use and benefits of technology in one's life in meeting needs, especially needs in doing business. Currently, many online shops have sprung up that provide various products that are needed by consumers. Before people recognized the Smart Phone, there were many entrepreneurs who carried out trading activities offline, but after the arrival of the Smart Phone, entrepreneurs changed their marketing method to online, this is a form of motivation for entrepreneurs to increase productivity. Based on this, the authors are interested in researching and evaluating the Effect of Social Networking on the Productivity of Online Businessmen with Motivation as a Moderation Variable. In this study, the population was all members of the LE Lancang Kuning Pekanbaru community in 2018, totaling 188 people and 30 samples were taken. \% of the total population so that there are 56 people using the random sampling method. The variable use of social social networks has a significant effect on the productivity of online shop businesses with a significant level of 0.00 $<0.05$. and the motivation variable has a significant effect on the productivity of business people with a significant level of $0.00<0.05$ and the use of online social networks (X) has no effect on productivity $(Y)$ motivation as a moderating variable with a significant level of $0.670>0.05$.
\end{abstract}

Keywords: Use of Social Networks, Productivity and Motivation

\begin{abstract}
ABSTRAK
Perkembangan teknologi yang semakin maju dan pesat serta diiringi dengan semakin tinggi tingkat kebutuhan penggunaan dan manfaat teknologi dalam kehidupan seseorang dalam memenuhi kebutuhan terutama kebutuhan dalam berbisnis. Saat ini banyak bermunculan toko-toko onlineshop yang menyediakan berbagai produk yang menjadi kebutuhan konsumen. Sebelum orang mengenali Smart Phone banyak wirausahawan yang melakukan kegiatan dagang secara offline tetapi setelah hadirnya Smart Phone para wirausahawan mengganti metode pemasarannya menjadi onlineshop, ini salah satu bentuk motivasi para wirausahawan dalam meningkatkan produktifitas. Berdasarkan hal tersebut, penulis tertarik ingin meneliti dan mengevaluasi mengenaiPengaruh Penggunaan Jejaring Sosial terhadap Produktifitas Pebisnis Onlineshop dengan Motivasi Sebagai Variable Moderasi.Dalam penelitian ini yang menjadi populasi adalah seluruh anggota komunitas LE Lancang Kuning Pekanbaru tahun 2018 yang berjumlah 188 orang dan yang menjadi sampel
\end{abstract}


diambil $30 \%$ dari total populasi sehingga berjumlah sebanyak 56 orangdengan menggunakan metode random sampling. Variabel penggunaan Jejaring sosial Sosial berpengaruh signifikan terhadap Produktivitas pebisnis onlineshop dengan tingkat signifikan sebesar $0,00<0,05$. dan variabel motivasi berpengaruh signifikan terhadap Produktivitas pebisnis dengan tingkat signifikan sebesar $0,00<0,05$ serta penggunaan Jejaring Sosial onlineshop (X)tidak berpengaruh terhadap produktivitas (Y) motivasi sebagai variabel moderasi dengan tingkat signifikan sebesar $0,670>0,05$.

Kata Kunci : Penggunaan Jejaring Sosial, Produktifitas dan Motivasi

\section{A. Latar Belakang Masalah}

Saat ini perkembangan teknologi sudah semakin maju dan pesat.Hal ini dikarenakan semakin tinggi tingkat kebutuhan penggunaan dan manfaat teknologi tersebut dalam kehidupan seseorang. Seperti perkembangan teknologi pada Handphone yang semakin hari semakin maju dan dilengkapi dengan fitur-fitur dan aplikasi yang sangat membantu pengguna dalam menyelesaikan sebagian persoalan kehidupan mereka dalam memenuhi kebutuhan, sebagai contoh dahulunya Handphone hanya berfungsi sebagai alat komunikasi yang hanya dilengkapi dengan fitur pesan suara, panggilan tunggu dan sms sedangkan saat sekarang Handphone menjadi multifungsi dan banyak menyediakan fiturfitur seperti adanya MP3, Player, kamera, game, televise dan fitur internet (online). Handphone menjadi Handphone Pintar (Smart Phone) yang didalamnya terdapat Operating System (OS).

Dengan adanya Operating System yang salah satunya support untuk aplikasi internet yang banyak digunakan para pengguna antara lain aplikasi jejaring sosial seperti facebook, instagram, WhatsApp, line, dan BBM sebagai media untuk berbisnis yakni munculnya berbagai onlineshop yang menyediakan berbagai produk yang menjadi kebutuhan konsumen. Sebelum orang mengenali Smart Phone banyak wirausahawan yang melakukan kegiatan dagang secara offline (buka toko) tetapi setelah hadirnya Smart Phone para wirausahawan mengganti metode pemasarannya menjadi onlineshop dan dengan adanya media online ini maka banyak bermunculan onlineshop, ini salah satu bentuk motivasi para wirausahawan meningkatkan produktifitas mereka. Berdasarkan informasi yang diperoleh dari media dengan situs webhttp://bisnis.liputan6.com, Kepala Badan Pusat Statistik (BPS) Suhariyanto mengatakan, dari Sensus Ekonomi 2016 yang dilakukan pihaknya, muncul data sementara jumlah e-commerce yang ada di Indonesia. Dalam kurun waktu10 tahun, jumlahe-commerce di Indonesia meningkat sekitar 17 persen. "Sampai sekarang kita baru tahu jumlah usahanya saja. Bahwa dari tahun 2006-2016, naik 17 persen. Jadi total jumlah usahanya sekitar 26,2 juta," Jakarta, Kamis (15/9/2016). 
Dari pengamatan ini, peneliti tertarik untuk melakukan penelitian dengan judul Pengaruh Penggunaan Jejaring Sosial terhadap Produktifitas Pebisnis Onlineshop dengan Motivasi Sebagai Variable Moderasi.

\section{B. TUJUAN PENELITIAN}

Berdasarkan perumusan masalah penelitian yang telah diuraikan di atas, maka penelitian ini bertujuan untuk :

1. Untuk mengetahui pengaruh penggunaan jejaring sosial terhadap produktifitas pebisnis onlineshop

2. Untuk mengetahui pengaruhmotivasi pebisnis onlineshop terhadap produktifitas pebisnis onlineshop?

3. Untuk mengetahui pengaruh penggunaan jejaring social terhadap produktifitas pebisnis onlineshop dengan motivasi sebagai variable moderasi

\section{LANDASAN TEORI}

\section{Pengertian Jejaring Sosial}

Situs jejaring sosial (bahasa Inggris: Social network sites) merupakan sebuah web berbasis pelayanan yang memungkinkan penggunanya untuk membuat profil, melihat list pengguna yang tersedia, serta mengundang atau menerima teman untuk bergabung dalam situs tersebut (Journal of Computer-Mediated Communication). Tampilan dasar situs jejaring sosial ini menampilkan halaman profil pengguna, yang di dalamnya terdiri dari identitas diri dan foto pengguna (Setiawan, 2008).

Kemunculan situs jejaring sosial ini diawali dari adanya inisiatif untuk menghubungkan orang-orang dari seluruh belahan dunia (Watkins, 2009). Pada awalnya situs-situs jejaring sosial isinya lebih banyak terkait hal-hal yang sifatnya "fun" dan nostalgia riatetapi selanjutnya terjadi perkembangan yang mengarah ke arah profesionalisme.

\section{Macam-Macam Situs Jejaring Sosial}

Terdapat ratusan situs jejaring sosial di berbagai belahan dunia yang sengaja dibuat untuk menghubungkan orang-orang dalam berinteraksi satu sama lain ( Lange. 2007). Berikut adalah daftar beberapa diantaranya sebagai berikut :
1. Facebook
2. Line
3. WhatsApp
4. Twitter
5. Instagram 


\section{Dampak Penggunaan Jejaring Sosial}

Jejaring sosial memiliki dampak tersendiri bagi para penggunanya antara lain:

\section{a. Dampak positif}

Dampak positif yang timbul dari penggunaan situs jejaring sosial antara lain sebagai berikut :

1. Semakin Mudahnya Berinteraksi dengan Orang Lain

2. Sarana Promosi

3. Sarana Sosialisasi Program Pemerintah

4. Sarana Silaturahmi

5. Sarana Hiburan

\section{b. Dampak Negatif}

Dampak negatif yang timbul dari penggunaan situs jejaring sosial adalah antara lain sebagai berikut :

1. Kurangnya Interaksi dengan Dunia Luar

2. Membuat Kecanduan

3. Pemborosan

4. Tergantikannya kehidupan sosial

5. Pornografi

6. Kesalahpahaman

7. Berkurangnya Perhatian Terhadap Keluarga

8. Sarana Kriminal

9. Mempengaruhi kesehatan.

\section{Motivasi}

\section{a. Pengertian Motivasi}

Menurut Robbins (2007), motivasi merupakan proses yang berperan pada intensitas, arah, dan lamanya berlangsung upaya individu ke arah pencapaian sasaran. Pengertian motivasi juga datang dari Marihot Tua E. H. (2002), yaitu faktor-faktor yang mengarahkan dan mendorong perilaku atau keinginan seseorang untuk melakukan suatu kegiatan yang dinyatakan dalam bentuk usaha keras atau lemah. 


\section{b. Teori Motivasi}

\section{b.1. Teori Motivasi Kebutuhan Maslow}

Maslow menyatakan bahwa manusia dimotivasi untuk memuaskan sejumlah kebutuhan yang melekat pada diri setiap manusia yang cenderung bersifat bawaan. Maslow mengatakan bahwa lima jenjang kebutuhan yang bersemayam dalam diri manusia terdiri dari :
1) Fisiologis
2) Keamanan
3) Sosial
4) Penghargaan
5) Aktualisasi Diri

\section{Pengertian Produktifitas}

Produktivitas merupakan perbandingan antara output dengan input perusahaan, industri dan ekonomi secara keseluruhan. Produktivitas kerja menurut Hasibuan (2007) adalah perbandingan antara output dengan input, di mana output-nya harus mempunyai nilai tambah dan teknik pengerjaan yang lebih baik. Sedangkan menurut T. Hani Handoko (2000) produktivitas adalah hubungan antara masukan-masukan dan keluaran-keluaran suatu sistem produktif. Dalam setiap usaha baik usaha perorangan, usaha segolongan warga negara maupun masyarakat selalu ada kecenderungan untuk meningkatkan produktivitas karyawan walupun motivasi pendorong peningkatan produktivitas kerja berbeda-beda antar perusahaan tersebut.

Pengukuran hasil suatu pekerjaan adalah dengan menilai unsur-unsur sebagai berikut (Mangkunegara, 2000).

1. Kualitas kerja

2. Ketepatan

3. Keterampilan

4. Ketelitian

5. Kebersihan

6. Kuantitas kerja

\section{F. Kerangka Pemikiran}

Penggunaan jejaring sosial tidak hanya berfungsi sebagai media komunikasi seseorang kepada keluarga, kerabat, dan rekan kerja semata. Jejaring sosial telah digunakan sebagai media promosi untuk memasarkan produk/jasa yang dijual kepada publik. Peningkatan penggunaan jejaring sosial yang dimanfaatkan sebagai media promosi atau pemasaran produk/jasa mendorong peningkatan pada produktivitas seseorang. Selain itu, motivasi 
juga menjadi variabel yang mempengaruhi produktivitas. Semakin tingginya keinginan dan intensi seseorang dalam melakukan promosi atau memasarkan produk/jasa yang dijualnya akan meningkatkan produktivitas.

Lebih lanjut, motivasi dalam memasarkan produk/jasa semakin diperkuat dengan pesatnya penggunaan jejaring sosial dan selanjutnya akan mendorong semakin tingginya produktivitas. Dengan kata lain, semakin tingginya motivasi akan memperkuat hubungan antara penggunaan jejaring sosial yang semakin pesat dan produktivitas yang semakin tinggi pula, dan sebaliknya. Untuk lebih jelasnya dapat digambarkan kerangka pemikiran penelitian sebagai berikut :

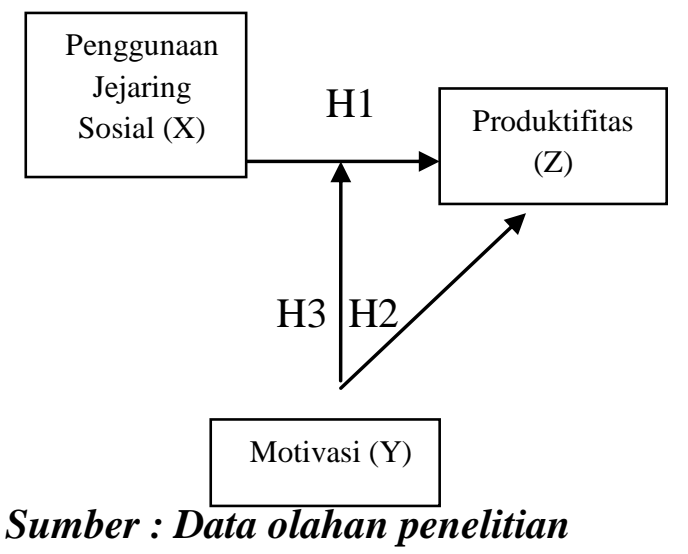

\section{G. Hipotesis}

Dari gambaran kerangka pemikiran di atas dapat ditarik hipotesis penelitian sebagai berikut :

H1 : Diduga penggunaan jejaring sosial berpengaruh signifikan terhadap produktivitas

H2 : Diduga motivasi berpengaruh signifikan terhadap produktivitas

H3 : Diduga penggunaan jejaring sosial berpengaruh signifikan terhadap produktivitas dengan motivasi sebagai variabel moderasi.

\section{H. Metodologi Penelitian}

\section{Objek Penelitian}

Penelitian ini dilaksanakan pada seluruh anggota komunitas LE Lancang Kuning Pekanbaru tahun 2018 yang berjumlah 188 orang. Adapun alasan pemilihan objek penelitian tersebut karena cara mendapatkan anggota yang selektif dan juga memiliki forum diskusi sesuai dengan klasifikasi jenis produk yang dijual, daerah dan jumlah 
pengikut. Melalui media sosial Facebook para pebisnis onlineshop dapat meraup keuntungan puluhan juta rupiah seiring meningkatnya jumlah anggota komunitas.

\section{Waktu Penelitian}

Penelitian akan dilaksanakan pada tahun 2018 dengan melakukan beberapa tahapan mulai dari pencarian data sekunder berupa jumlah populasi dan sampel pada akhir bulan januari, pembuatan proposal penelitian pada awal februari. Sedangkan untuk penyebaran kuesioner sampai pengumpulan kuesioner dilaksanakan pada bulan juli hingga agustus dan pengolahan data beserta pembahasan hasil penelitian dilaksanakan pada bulan september hingga oktober.

\section{Populasi dan Sampel}

Populasi dalam penelitian ini adalah seluruh anggota komunitas LE Lancang Kuning Pekanbaru tahun 2018 yang berjumlah 188 orang. Sampel adalah sebagian atau wakil dari populasi yang akan diteliti, apabila jumlah subjek dibawah 100 orang maka sampel diambil semua populasi, dan apabila jumlah subjek diatas 100 orang dapat maka sampel diambil 10-15\% atau 20-25\% atau lebih dari jumlah populasi (Suharsimi Arikunto, 2010).

Metode pengambilan sampel menggunakan random sampling.Pada penelitian ini pengambilan sampel sebanyak $30 \%$ dengan jumlah sebanyak 56 orang.

\section{Jenis Dan Sumber Data}

Jenis data yang digunakan dalam penelitian ini terdiri dari data primer dan sekunder. Data primer berupa data responden (lama bergabung di komunitas, umur, pendidikan, pekerjaan, jenis produk yang dijual, lamanya bergabung dalam komunitas,pendapatan), motivasi dan produktivitas. Data sekunder berupa jumlah Ibu-ibu yang tergabung dalam komunitas per kurun waktu tertentu (bulan dan tahun).

\section{Metode Pengumpulan Data}

Metode pengumpulan data dalam penelitian ini dilakukan dengan menggunakan metode kuesioner (dafar pernyataan) dan wawancara. Kuesioner yang telah disusun, merupakan rangkaian-rangkaian pertanyaan yang berkaitan dengan penggunaan jejaring sosial, motivasi dan produktivitas.

Kuesioner tersebut dibedakan menjadi kuesioner tertutup yaitu responden hanya diberi kesempatanuntuk memilih jawaban yang telah disediakansesuai dengan pendapatnya,dankuesioner terbukayaituresponden diberi kesempatan untuk menjawab sesuaidengan pendapatnya secara bebas.

Pernyataan-pernyataan dalam kuesioner tersebut disertai jawaban dengan menggunakan skala likert yang mana : 
SS : Sangat Setuju (Skala 4)

S : Setuju (Skala 3)

TS : Tidak Setuju (Skala 2)

STS : Sangat Tidak Setuju (Skala 1)

Data-data dari kuesioner tersebut akan diinput kedalam program SPSS dan diolah. Sedangkan wawancara dilakukan kepada beberapa Ibu-ibu yang dipilih secara acak (random) untuk menanyakan informasi relevan yang diperlukan terkait penelitian ini, yaitu mengenai jumlah Ibu-ibu yang tergabung dalam komunitas per jangka waktu tertentu, mekanisme pelaporan, pendapatan, dan lainnya.

\section{Pengolahan Data}

\section{a. Uji Validitasdan Uji Reliabilitas}

\section{Uji Validitas}

Hasil penelitian akan baik apabila menggunakan metode pengumpulan data yangtepat dan dalam penelitian ini akan lebih memfokuskan dengan metode kuesionersebagaimana dikemukakan Sunyoto (2009) pengukuran dapat dilakukan dengan One shotatau sekali saja.Menurut Nawawi (2006) bahwa instrumen penelitian harus dipilih yang mampumengumpulkan data atau informasi secara lengkap, tepat/benar atau relevan denganmasalahnya dan obyektif.Data atau informasi yang dihimpun itu harus dapat dipergunakan untuk mengujihipotesis penelitian atau sekurang-kurangnya mampu menjawab atau memecahkan masalahyang hendak diungkapkan. Dengan kata lain hasil penelitian tidak dipandang ilmiah, apabilatidak mempergunakan instrumen yang memenuhi persyaratan validitas, reliabilitas, dandapat dipertanggungjawabkan.

\section{Uji Reliabilitas}

Untuk mengetahui konsistensi dan keajegan data perlu dilakukan uji reliabilitasmenurut Nawawi (2006) dimana instrumen yang memiliki tingkat reliabilitas tinggicenderung menghasilkan data yang sama tentang suatu variabel atau unsurunsurnya.Pengujian dilakukan dengan rumus Spearman Brown Sugiono (2007), Sandjadja dkk (2006)atau dengan menggunakan SPSS Versi 13 dengan teknik Alpha Cronbach, Arikunto (2002), apabila nilai koefisien Cronbach Alpha > 0,60 atau tinggi maka instrumen dapat digunakan.

\section{b. Uji Normalitas}

Uji normalitas data bertujuan untuk menguji apakah data terdistribusi secara normal. Jika distribusi data tidak normal, maka tes statistik yang dihasilkan tidak valid. Pada penelitian ini untuk menguji normalitas data digunakan normal probability plot. Pada pendekatan ini distribusi normal ditunjukkan dalam garis diagonal, sedangkan residul dari data aktual akan diploat sesuai dengan distribusinya. Jika plotting actual terletak pada garis diagonal tersebut atau mendekatinya, berarti data aktual tersebut berdistribusi normal. 
Namun apabila data tersebut tersebar menjauhi garis diagonal, maka dapat dipastikan bahwa distribusi data tersebut tidak normal(Santoso, $2005: 270$ ).

\section{c. Uji Analisa Data}

Didalam menganalisa data telah dikumpulkan maka penulis menggunakan metode kuantitatif dan deskriptif.

1) Analisis Deskriptif yaitu merupakan suatu cara menganalisa data yang telah tersedia pada objek penelitian dan membandingkan dengan uraian teoritis dari berbagai literatur yang terdapat dalam daftar pustaka.

2) Analisis Kuantitatif, yaitu melakukan perhitungan terhadap data yang diperoleh untuk melakukan suatu pengukuran terhadap hal-hal tertentu, maka penulis melakukan analisa regresi Linier berganda, antara variabel bebas (budaya organisasi dan kepemimpinan) dengan variabel interverning (kepuasan kerja) dan variabel terikat (Kinerja) persamaan :

$\mathrm{Y}=\mathrm{a}+\mathrm{b}_{1} \mathrm{X}+\mathrm{b}_{2} \mathrm{Z}+\mathrm{b}_{3} \mathrm{XZ}+\mathrm{e}$

Dimana :

$\mathrm{a}=$ Konstanta

$\mathrm{b} \quad=$ Koefisien Regresi

$\mathrm{X}=$ Penggunaan Jejaring Sosial

$\mathrm{Z}$ =Produktivitas (Variabel Moderasi)

$\mathrm{Y}=$ Motivasi

$\mathrm{e}=$ Variabel error

\section{d. Pengujian Hipotesis}

\section{Uji T (Parsial)}

Pengujian ini bertujuan untuk memastikan apakah variabel independen yang terdapat dalam persamaan terdapat secara individu berpengaruh terhadap variabel independen. Uji t dilakukan dengan membandingkan $t$ hitung dengan $t$ tabel pada tingkat signifikan 5\%(Mangkuadmodjo: 2004).

\section{Uji F (Silmutan)}

Digunakan untuk menguji apakah semua variabel secara bersama-sama (simultan) mempunyai pengaruh terhadap variabel terikat dengan cara (Mangkuadmodjo: 2004) :

1) Membandingkan $f$ rasio dengan $f$ tabel, yaitu apabila rasio lebih besar dari pada $f$ tabel ( $\mathrm{f}$ rasio > f tabel) berarti variabel bebas secara bersama-sama berpengaruh sangat nyata terhadap variabel tidak bebas, tetapi apabila $F$ rasio lebih kecil daripada $F$ tabel ( $F$ rasio $<\mathrm{F}$ tabel) berarti variabel bebas tidak berpengaruh secara nyata terhadap variabel tidak bebas.

2) Berdasarkan koefisien determinasi $\left(R^{2}\right)$ terhadap variabel bebas. Syarat determinasi $\left(R^{2}\right)$ dikatakan kuat atau lemah yaitu apabila $\left(\mathrm{R}^{2}\right)$ mendekati angka 1 , maka berarti pengaruh 
variabel bebas secara serentak (bersama-sama) dianggap kuat dan apabila $\left(\mathrm{R}^{2}\right)$ mendekati nol maka pengaruh variabel bebas terhadap variabel terikat serentak adalah lemah.

\section{Hasil Penelitian \\ 1. Tanggapan Responden}

Sesuai dengan objek penelitian dari tanggapan responden tentang penggunaan jejaring sosial terhadap produktifitas pebisnis onlineshop, pengaruh motivasi pebisnis onlineshop terhadap produktifitas pebisnis onlines, pengaruh penggunaan jejaring sosial terhadap produktifitas pebisnis onlineshop dengan motivasi sebagai variabel moderasi pada seluruh anggota komunitas LE Lancang Kuning Pekanbaru tahun 2018 yang berjumlah 188 orang, dimana diambil sampel $30 \%$ dari jumlah tesebut yaitu 56 orang.

\section{Deskriptif Variabel Penelitian}

Dalam penelitian ini variabel independen yang digunakan adalah pengaruh penggunaan sosial, sedangkan variabel dependen adalah produktivitas dan motivasi sebagai variabel moderasinya. Untuk keseluruhan dari responden penelitian berjumlah 56 orang.

\section{Deskriptif Tanggapan Responden}

\section{a.Variabel Independen(Penggunaan Jejaring Sosial)}

Berdasarkan pengujian validitas dari 11 (sebelas) item pernyataan konsep yang menghasilkan uji realibilitas adalah sebesar 0,895 nilai tersebut lebih besar dari 0,6 sehingga dapat dikatakan bahwa item pernyataan kuesioner yang dibuat sangat baik dijadikan sebagai alat penelitian untuk mengukur penggunaan Jejaring Sosial karena tingkat keakuratan sebesar 89,5\%.

Kemudian, pernyataan responden menurut kategori skala likert menunjukkan bahwa masing-masing mempunyai kategori yang berbeda-beda, untuk mengetahui kategorinya dapat diperhatikan pada Tabel 1 dibawah ini :

Tabel. 1

Rekapitulasi Tanggapan Responden Mengenai Item Pernyataan Penggunaan Jejaring Sosial

\begin{tabular}{|c|l|c|c|c|c|}
\hline No & \multicolumn{3}{|c|}{ Penggunaan Jejaring Sosial } & \multicolumn{4}{|c|}{ Jawaban } \\
\cline { 4 - 6 } & 4 & 3 & 2 & 1 \\
\hline PJS 1 & $\begin{array}{l}\text { Jejaring sosial memudahkan saya dalam memberikan } \\
\text { informasi produk yang saya tawarkan kepada pelanggan }\end{array}$ & 41 & 15 & 0 & 0 \\
\hline PJS 2 & $\begin{array}{l}\text { Jejaring sosial memudahkan saya untuk terus berinteraksi } \\
\text { dengan calon pelanggan }\end{array}$ & 17 & 0 & 0 \\
\hline
\end{tabular}




\begin{tabular}{|l|l|c|c|c|c|}
\hline PJS 3 & $\begin{array}{l}\text { Jejaring sosial memiliki jaringan yang luas dalam melakukan } \\
\text { kegiatan pemasaran produk }\end{array}$ & 12 & 0 & 0 \\
\hline PJS 4 & $\begin{array}{l}\text { Jejaring sosial mampu meningkatkan popularitas produk } \\
\text { yang saya miliki }\end{array}$ & 21 & 0 & 0 \\
\hline PJS 5 & $\begin{array}{l}\text { Dengan menggunakan jejaring sosial, biaya promosi relatif } \\
\text { lebih murah dari media promosi lainnva }\end{array}$ & 21 & 1 & 0 \\
\hline PJS 6 & $\begin{array}{l}\text { Jejaring sosial memudahkan saya dalam menentukan pasar } \\
\text { produk yang ditargetkan }\end{array}$ & 32 & 4 & 0 \\
\hline PJS 7 & $\begin{array}{l}\text { Jejaring sosial menyediakan fitur yang beragam dan } \\
\text { tampilan yang menarik }\end{array}$ & 32 & 2 & 0 \\
\hline PJS 8 & $\begin{array}{l}\text { Jejaring sosial mampu memberikan informasi yang akurat } \\
\text { seputar produk yang saya jual }\end{array}$ & 36 & 2 & 0 \\
\hline PJS 9 & $\begin{array}{l}\text { Fitur hastag yang ada pada jejaring sosial memudahkan saya } \\
\text { dalam mempromosikan produk }\end{array}$ & 38 & 0 & 0 \\
\hline PJS 10 & $\begin{array}{l}\text { Melalui jejaring sosial promosi dapat dilakukan berulang- } \\
\text { ulang }\end{array}$ & 20 & 0 & 0 \\
\hline PJS 11 & $\begin{array}{l}\text { Setelah mempromosikan produk di jejaring sosial, feedback } \\
\text { dari pelanggan dapat diterima }\end{array}$ & 31 & 0 & 0 \\
\hline
\end{tabular}

Sumber : Data Olahan Penelitian 2018

Tabel. 2

\section{Rekapitulasi Nilai Rata-rata Item Pernyataan Penggunaan Jejaring Sosial}

\begin{tabular}{|c|c|c|c|c|}
\hline Item & $\mathrm{N}$ & Minimum & Maksimum & Rata-rata \\
\hline PJS 1 & 56 & 3 & 4 & 3,73 \\
\hline PJS 2 & 56 & 3 & 4 & 3,70 \\
\hline PJS 3 & 56 & 3 & 4 & 3,79 \\
\hline PJS 4 & 56 & 3 & 4 & 3,63 \\
\hline PJS 5 & 56 & 2 & 4 & 3,59 \\
\hline PJS 6 & 56 & 2 & 4 & 3,32 \\
\hline PJS 7 & 56 & 2 & 4 & 3,36 \\
\hline PJS 8 & 56 & 2 & 4 & 3,29 \\
\hline PJS 9 & 56 & 3 & 4 & 3,32 \\
\hline PJS 10 & 56 & 3 & 4 & 3,64 \\
\hline PJS 11 & 56 & 3 & 4 & 3,45 \\
\hline PENGGUNAAN JEJARING SOSIAL & 3.53 \\
\hline
\end{tabular}

Sumber : Data Olahan Penelitian 2018

Secara umum penggunaan jejaring sosial olehpebisnis onlineshop berada pada kategori baik dengan nilai sebesar 3,53. Berdasarkan dari 11 (sebelas) item pertanyaan tersebut bahwa nilai rata-rata 3 (tiga) yang tertinggi secara berurutan yaitu PJS3, PJS 1, dan PJS 2. 


\section{VariabelDependen (Produktifitas)}

Berdasarkan pengujian validitas dari 5 (lima) item pertanyaan produktivitas, dapat dilihat dari uji realibilitas adalah sebesar 0,804 nilai tersebut lebih besar dari 0,6 sehingga dapat dikatakan bahwa item pernyataan kuesioner yang dibuat cukup baik dijadikan sebagai alat penelitian untuk mengukur produktivitas pebisnis onlineshop karena tingkat keakuratan sebesar 80,4\%.

Pernyataan responden menurut kategori skala likert menunjukkan bahwa masing-masing mempunyai kategori yang berbeda-beda, untuk mengetahui kategorinya dapat diperhatikan pada Tabel 3dibawah ini :

Tabel. 3.

Rekapitulasi Tanggapan Responden Mengenai Item Pernyataan Produktivitas

\begin{tabular}{|c|l|c|c|c|c|}
\hline No & \multicolumn{1}{|c|}{ Penggunaan Jejaring Sosial } & \multicolumn{3}{|c|}{ Jawaban } \\
\cline { 4 - 6 } & \multicolumn{1}{|c|}{$\begin{array}{l}|c| \\
\text { P1 }\end{array}$} & $\begin{array}{l}\text { Saya memiliki keterampilan yang sangat baik dalam } \\
\text { melaksanakan bisnis }\end{array}$ & 47 & 2 & 0 \\
\hline P2 & $\begin{array}{l}\text { Saya sangat menjaga ketepatan waktu dan kesempurnaan } \\
\text { hasil (produk) bisnis }\end{array}$ & 16 & 36 & 4 & 0 \\
\hline P3 & Kualitas produk yang saya miliki telah memenuhi standar & 16 & 39 & 1 & 0 \\
\hline P4 & $\begin{array}{l}\text { Saya selalu berusaha untuk meningkatkan kualitas produk } \\
\text { bisnis saya }\end{array}$ & 22 & 0 & 02 \\
\hline P5 & $\begin{array}{l}\text { Saya selalu mengevaluasi produk yang telah dihasilkan guna } \\
\text { memperbaiki kualitas }\end{array}$ & 29 & 0 & 0 \\
\hline
\end{tabular}

Sumber : Data Olahan Penelitian 2018 
Tabel. 4.

Rekapitulasi Nilai Rata-rata Item Pernyataan

Produktivitas

\begin{tabular}{|c|c|c|c|c|}
\hline Item & $\mathrm{N}$ & Minimum & Maksimum & Rata-rata \\
\hline P1 & 56 & 2 & 4 & 3,09 \\
\hline P2 & 56 & 2 & 4 & 3,21 \\
\hline P3 & 56 & 2 & 4 & 3,27 \\
\hline P4 & 56 & 3 & 4 & 3,61 \\
\hline P5 & 56 & 3 & 4 & 3,52 \\
\hline \multicolumn{5}{|c|}{ PRODUKTIVITAS } \\
\hline
\end{tabular}

Sumber : Data Olahan Penelitian 2018

Secara umum produktifitas yang dimilikipebisnis onlineshop berada pada kategori baik dengan nilai sebesar 3,34. Berdasarkan dari 5 (lima) item pertanyaan tersebut bahwa nilai rata-rata 3 (tiga) yang tertinggi secara berurutan yaitu P5, P4, dan P3.

\section{Variabel Moderasi (Motivasi)}

Motivasi kerja positif adalah suatu dorongan yang diberikan oleh seorang karyawan untuk bekerja dengan baik, dengan maksud mendapatkan kompensasi untuk mencukupi kebutuhan hidupnya dan berpartisipasi penuh terhadap pekerjaan yang ditugaskan oleh perusahaan/organisasinya. Berdasarkan pengujian validitas dari 12 (duabelas) item pertanyaan produktivitas, dapat dilihat dari uji realibilitas adalah sebesar 0,918 nilai tersebut lebih besar dari 0,6 sehingga dapat dikatakan bahwa item pernyataan kuesioner yang dibuat cukup baik dijadikan sebagai alat penelitian untuk mengukur produktivitas pebisnis onlineshop karena tingkat keakuratan sebesar 91,8\%.

Kemudian, pernyataan responden menurut kategori skala likert menunjukkan bahwa masing-masing mempunyai kategori yang berbeda-beda, untuk mengetahui kategorinya dapat diperhatikan pada Tabel 5 dibawah ini : 
Tabel. 5.

Rekapitulasi Tanggapan Responden Mengenai Item Pernyataan Motivasi

\begin{tabular}{|l|l|c|c|c|c|}
\hline \multirow{2}{*}{ No } & \multicolumn{1}{|c|}{ Penggunaan Jejaring Sosial } & \multicolumn{3}{|c|}{ Jawaban } \\
\cline { 3 - 6 } & & 4 & 3 & 2 & 1 \\
\hline M1 & Saya merasa bahwa kebutuhan dasar sudah dipenuhi & 8 & 41 & 7 & 0 \\
\hline M 2 & $\begin{array}{l}\text { Saya merasa dengan adanya bisnis ini, kebutuhan rumah } \\
\text { tangga terpenuhi }\end{array}$ & 9 & 36 & 9 & 2 \\
\hline M3 & $\begin{array}{l}\text { Saya merasa banyak hasil yang lebih dari sebelumnya } \\
\text { yang saya dapatkan dari bisnis ini }\end{array}$ & 12 & 36 & 7 & 1 \\
\hline M4 & Saya merasa cocok dengan bisnis ini & 20 & 30 & 6 & 0 \\
\hline M5 & Bisnis ini dapat menjamin kehidupan saya & 10 & 29 & 17 & 0 \\
\hline M6 & Saya merasa mendapatkan rekan bisnis yang baik & 16 & 36 & 4 & 0 \\
\hline M7 & Saya selalu dilibatkan dalam pertemuan bisnis & 10 & 32 & 13 & 1 \\
\hline M 8 & Hasil bisnis saya semakin berkembang & 11 & 36 & 7 & 2 \\
\hline M9 & Saya merasa senang menjalani bisnis ini & 21 & 32 & 3 & 0 \\
\hline M 10 & Saya ingin bisnis saya semakin berkembang & 41 & 14 & 1 & 0 \\
\hline M 11 & Saya merasa tertantang dengan bisnis ini & 25 & 27 & 4 & 0 \\
\hline M12 & Bisnis ini dapat meningkatkan potensi saya untuk lebih & 29 & 26 & 1 & 0 \\
\hline
\end{tabular}

\section{Sumber : Data Olahan Penelitian 2018}

Tabel. 6

\section{Rekapitulasi Nilai Rata-rata Item Pernyataan Motivasi}

\begin{tabular}{|c|c|c|c|c|}
\hline Item & $\mathrm{N}$ & Minimum & Maksimum & Rata-rata \\
\hline M 1 & 56 & 2 & 4 & 3,02 \\
\hline M 2 & 56 & 1 & 4 & 2,93 \\
\hline M3 & 56 & 1 & 4 & 3,05 \\
\hline M4 & 56 & 2 & 4 & 3,25 \\
\hline M5 & 56 & 2 & 4 & 2,88 \\
\hline M6 & 56 & 2 & 4 & 3,21 \\
\hline M 7 & 56 & 1 & 4 & 2,91 \\
\hline M & 56 & 1 & 4 & 3,00 \\
\hline M & 56 & 2 & 4 & 3,32 \\
\hline M 10 & 56 & 2 & 4 & 3,71 \\
\hline M 11 & 56 & 2 & 4 & 3,38 \\
\hline M 12 & 56 & 2 & 4 & 3,50 \\
\hline \multicolumn{7}{|l}{ MOTIVASI } & 3.18 \\
\hline
\end{tabular}

Sumber : Data Olahan Penelitian 2018

Secara umum motivasi yang dimilikipebisnis onlineshop berada pada kategori baik dengan nilai sebesar 3,18. Berdasarkan dari 12 (dua belas) item pertanyaan tersebut bahwa 
nilai rata-rata 3 (tiga) yang tertinggi secara berurutan yaitu M10, M12, dan M1

\section{Pengujian Hipotesis}

Variabel Penggunaan Jejaring Sosial (X)berpengaruh terhadap produktivitas (Y) sebesar 0,391. Selajutnya, uji keputusan ini secara parsial apakah signifikan atau tidak dapat dibuktikan dengan nilai T hitung sebesar 4,657dengan tingkat signifikan sebesar 0,00 $<0,05$, hal ini menunjukkan bahwa penggunaan Jejaring sosial Sosial berpengaruh signifikan terhadap Produktivitaspebisnis online shop sehingga $\mathrm{Ha}$ diterima dan Ho ditolak.

Variabel motivasi(Z)berpengaruh terhadap produktivitas (Y) sebesar 0,585 . Selajutnya, uji keputusan ini secara parsial apakah signifikan atau tidak dapat dibuktikan dengan nilai $\mathrm{T}$ hitung sebesar 6,957dengan tingkat signifikan sebesar $0,00<0,05$, hal ini menunjukkan bahwa motivasiberpengaruh signifikan terhadap Produktivitaspebisnis online shop sehingga Ha diterima dan Ho ditolak.

Variabel Penggunaan Jejaring Sosial (X)tidak berpengaruh terhadap produktivitas (Y) sebagai variabel moderasinya sebesar $-0,524$. Selajutnya, uji keputusan ini secara parsial apakah signifikan atau tidak dapat dibuktikan dengan nilai $\mathrm{T}$ hitung sebesar 0,429dengan tingkat signifikan sebesar 0,670 > 0,05, hal ini menunjukkan bahwa Jejaring Sosial (X)tidak berpengaruh terhadap produktivitas (Y) sebagai variabel moderasinya sehingga Ha ditolak dan Ho diterima.

\section{Pembahasan}

Dalam pembahasan ini bermaksud mengevaluasi pengaruh penggunaan Jejaring Sosial terhadap Produktivitas Pebisnis Onlineshop dengan Motivasi sebagai Variabel Moderasi. Dari hasil pengujian penggunaan Jejaring Sosial mempengaruhi Produktivitas pebisnis onlineshop sebesar 0,704 atau $70,4 \%$, hal ini menunjukkan bahwa setiap indikator yang melekat dalam penggunaan jejaring sosial (terlampir pada kuesioner) mempengaruhi produktifitas pebisnis onlineshop. Akan tetapi, Varibel Moderasi (motivasi) tidak memiliki pengaruh signifikan terhadap produktifitas pebisnis onlineshop.Hal ini diasumsikan bahwa motivasi pebisnis onlineshop yang menjadi objek penelitian ini masih rendah dikarenakan sampel berasal dari ibu-ibu rumah tangga yang memiliki jiwa bisnis dan kemampuan/skill dalam menghasilkan produk makanan sehingga hasil penjualan hanya sekedar untuk membantu memenuhi kebutuhan rumah tangga.

\section{K. Kesimpulan}

Berdasarkan penelitian maka dapat disimpulkan beberapa hal sebagai berikut:

1. Variabel Penggunaan Jejaring Sosialsecara simultan berpengaruh signifikan terhadap Produktivitas Pebisnis Onlineshop sebesar 70,4\% dan sisanya 29,6 \% dipengaruhi 
oleh variabel lain yang tidak diteliti pada penelitian ini.

2. Varibel Penggunaan Jejaring Sosial(X) tidak berpengaruh signifikan terhadap Produktivitas Pebisnis Onlineshop (Y) dengan Motivasi (Z) sebagai variable Moderasi dengan tingkat sebesar $0,670>0,05$.

3. Berdasarkan hasil jawaban kuesioner menunjukkan bahwa Penggunaan Jejaring Sosial dapat meningkatkan produktifitas pebisnis onlineshop.

\section{Saran}

Berdasarkan analisis pembahasan penelitian yang telah diuraikan dimuka, maka ada beberapa saraitan sebagai bahan pertimbangan selanjutnya yaitu:

1. Bagi Pebisnis onlineshop lengkapi media jejaring sosial dengan hastag sehingga konsumen dengan mudah melihat ketersediaan produk.

2. Untuk meningkatkan produktifitas follow up pelanggan pasca pembelian dengan mengirimkan promo-promo produk melalui jejaring sosial seperti WhatsApp ataupun instagram

3. Manfaatkan fasilitas Jejaring Sosial Aplikasi Instagram untuk memperlihatkan produkproduk yang ditawarkankemudian follow keberlanjutan transaksi menggunakan aplikasi WhatsApp. 


\section{DAFTAR PUSTAKA}

Bungin, Burhan. 2005. Metode Penelitian Kuantitatif. Jakarta : Penerbit Prenada Media.

Ghozali, Imam. 2005. Aplikasi Analisis Multivariate Dengan Program SPSS. Cetakan IV. Semarang. BP. UNDIP.

Hasibuan, Malayu S.P. (2009), Manajemen Sumber Daya Manusia, Edisi Revisi, Cetakan ketiga belas, Jakarta : PT. Bumi Aksara.

Kreitner, Robert dan Angelo Kinicki. 2014. Organizational Behavioral. Edisi 5.Boston : McGraw-Hill.

Mangkunegara, A.A.Anwar Prabu. 2007. Manajemen Sumber Daya Perusahaan. PT. Remaja Rosdakarya. Bandung

Mathis, Robert L. dan Jackson, John H., 2006. Human Resources Management. Edisi sepuluh, Jakarta : Penerbit Salemba Empat.

Peraturan Pemerintah (PP) No. 10 Tahun 1979 Tentang Penilaian Pelaksanaan Pekerjaan PNS (DP-3)

Peraturan Pemerintah (PP) Nomor 46 Tahun 2011 Tentang Penilaian Prestasi Kerja Pegawai Negeri Sipil.

Santoso, Singgih. 2006. Menggunakan SPSS untuk Statistik Non Parametrik. PT. Elex Media Komputindo, Jakarta.

Setiawan, Dirgayuza. 2008. Gaul Ala Facebook untuk Pemula. Jakarta: Media Kita.

Simanjuntak, Payaman J. 2005. Manajemen dan Evaluasi Kinerja. Jakarta: Lembaga Penerbit Fakultas Ekonomi UI.

Sugiyono, (2008). Metode Penelitian Kunatitatif Kualitatif dan R\&D. Bandung : Alfabeta.

Watkins, S.Craig. 2009. The Young and the Digital: What the Migration to Social Network Sites, Games, and Anytime, Anywhere Media Means for Our Future.'UK: Beacon Press.

Ani, M. 2012.Manajemen Sumber Daya Manusia. Mitra Wacana Media. Jakarta.

Zadjuli, H.A. 2006.Kaida-kaidah Fikih.Jakarta : Kencana

Guritno, Bambang dan Waridin. 2005. Pengaruh Persepsi Karyawan Mengenai Perilaku Kepemimpinan, Kepuasan Kerja Dan Motivasi Terhadap Kinerja.JRBI. Vol 1. No 1. Hal: 63-74.

Hamali, Arif Yusuf. 2013. Journal The WINNERS. Vol 14. No 2. Hal: 77-86. 
Lange, P. G. (2007). Publicly private and privately public: Social networking on YouTube. Journal of Computer-Mediated Communication, 13(1), article 18.

Manalu, Elpis Anto, dkk. 2014. Pengaruh Motivasi, Kepemimpinan dan Disiplin Terhadap Produktivitas Kerja Pegawai Dinas Kehutanan dan Perkebunan Kabupaten Tapanuli Tengah. Jurnal Bisnis dan Manjemen Eksekutif. Vol 1. No 1.

Purnama, Ridwan. Pengaruh Motivasi Kerja Terhadap Produktivitas Kerja Karyawan pada Bagian Produksi CV. Epsilon Bandung. Jurnal Strategic. Vol 7. No 14. Hal: 5882.

Rahmawati, Desi. 2013. Pengaruh Motivasi terhadap Produktivitas Kerja Karyawan PR Fajar Berlian Tulungagung. Jurnal Universitas tulungagung BONOROWO. Vol 1. No 1. Hal: 1-16.

Rahmawati, Rini. 2010. Pengaruh Motivasi terhadap Produktivitas Kerja Karyawan PT Permodalan Nasional Madani Banjarmasin. Jurnal Manajemen dan Akuntansi. Vol 11. No 1. Hal: 63-67.

Social Network Sites: Definition, History, and Scholarship. Journal of Computer-Mediated Communication, 13(1), article 11.

Yasundari. 2016. Hubungan Penggunaan Instagram dengan Motivasi Wirausaha Pebisnis Daring (Online) dalam Meningkatkan Produktivitas. Jurnal Kajian Komunikasi. Vol 4. No 2. Hal: 208-218. 